\title{
TWENTY-YEAR EXPERIENCE WITH LARGE LOOP EXCISION OF THE TRANSFORMATION ZONE AT SESTRE MILOSRDNICE UNIVERSITY HOSPITAL CENTRE
}

\author{
Dražan Butorac ${ }^{1}$, Bernarda Škrtić ${ }^{2}$, Marijo Čukelj ${ }^{1}$, Krunoslav Kuna ${ }^{1}$ and Ivka Djaković1 \\ ${ }^{1}$ Department of Obstetrics and Gynecology, Sestre milosrdnice University Hospital Centre, Zagreb, Croatia; \\ ${ }^{2}$ Department of Obstetrics and Gynecology, Karlovac General Hospital, Karlovac, Croatia
}

\begin{abstract}
SUMMARY - The 20-year experience with large loop excision of the transformation zone (LLETZ) at Gynecologic Oncology Unit, Department of Gynecology and Obstetrics, Sestre milosrdnice University Hospital Centre from Zagreb is presented. This retrospective observational study included 1407 women with cervical dysplasia treated by LLETZ technique during the 1995-2016 period. LLETZ was most commonly performed in the 25-35 age group (51\%), followed by the 36-45 age group (22\%), and least frequently in the $>65$ age group (2\%). Histopathologic results lower than high-grade squamous intraepithelial lesion were found in $23 \%$ and high grade squamous intraepithelial lesion or worse findings in $77 \%$ of patients. Positive margin as a sign of possible residual dysplasia was found in $25 \%$ of cones, $80 \%$ of which included endocervical positive margin. Cervical canal biopsy result was positive in $18 \%$ of cases. Accurate colposcopy and its findings can help avoid overtreatment, the rate of which was higher than expected in our retrospective study. Long-term follow up is an imperative for proper assessment of the procedure success. This method is the best choice for complete disease removal without unnecessary overtreatment, but it requires continuous education and training of the whole team.
\end{abstract}

Key words: Conization; Cervical intraepithelial neoplasia; Uterine cervical dysplasia; Colposcopy; Croatia

\section{Introduction}

Large loop excision of the transformation zone (LLETZ) is an inexpensive and simple first choice of minimally invasive surgical gynecologic treatment of premalignant and early malignant cervical lesions. Proper understanding the disease along with right indication set for operative procedure and patient informed consent considering its limitations, complications and possible treatment failure are prerequisites for good outcome of the procedure. In comparison to cold knife cone biopsy, it has many advantages ${ }^{1-4}$.

Correspondence to: Ivka Djakovic, $M D, P h D$, Department of Gynecology and Obstetrics, Sestre milosrdnice University Hospital Centre, Vinogradska c. 29, HR-10000 Zagreb, Croatia

E-mail: ivkadj@yahoo.com

Received February 7, 2019, accepted March 19, 2019
The purpose of this study was to review the 20-year experience with LLETZ in the Gynecologic Oncology Unit, Department of Gynecology and Obstetrics, Sestre milosrdnice University Hospital Centre in Zagreb.

\section{Materials and Methods}

This retrospective observational study included 1407 women with cervical dysplasia treated with LLETZ technique during the 1995-2016 period. $\mathrm{Pa}-$ tients were divided into subgroups according to age, cone biopsy and cone margin results, and histopathologic findings of the excochleated cervical canal. Cervical cytology, followed by colposcopy evaluation and colposcopy-directed biopsy were performed in all 
patients to confirm cervical dysplasia. All patients signed the informed consent form to participate in the study, which was approved by the institutional Ethics Committee.

\section{Results}

Patient distribution according to age showed that LLETZ was most commonly performed in the 25-35 age group (51\%), followed by the 36-45 age group $(22 \%)$, and least frequently in the $>65$ age group (2\%). Histopathologic findings lower than high-grade squamous intraepithelial lesion (HSIL) were recorded in $23 \%$ and HSIL or worse findings in $77 \%$ of patients. Four $(0.29 \%)$ patients were diagnosed with invasive squamous cell carcinoma or adenocarcinoma. Positive margin as a sign of possible residual dysplasia was found in $25 \%$ of cones, $80 \%$ of which included endocervical positive margin. Cervical canal biopsy result was positive in $18 \%$ of cases.

\section{Discussion}

Large loop excision of the transformation zone is a simple and rapid technique which is highly favored by gynecologists and patients in therapy of premalignant and early malignant cervical lesions because of its numerous advantages ${ }^{1,2}$. LLETZ offers individual approach to each patient with good performance and avoidance of excessive excision thanks to the availability of diverse shapes and size of loops ${ }^{1-4}$.

Premalignant and early malignant cervical lesions can be found at any age, but the 25-35 age group is most vulnerable ${ }^{5}$. These patients are of childbearing age and the need of minimally invasive surgical gynecologic treatment for these lesions is more pronounced than in older age groups, as demonstrated by the figure of $51 \%$ conducted LLETZ procedures in the 25-35 age group recorded in our study. LLETZ is a procedure associated with a lower rate of complications than cold knife conization, such as postoperative bleeding and cervical stenosis, as well as a lower rate of preterm births, perinatal mortality and morbidity ${ }^{6-8}$.

In $77 \%$ of our patients, histopathologic finding confirmed colposcopy evaluation and colposcopy-directed biopsy, or it was worse. Four (0.29\%) patients were diagnosed with invasive squamous cell carcinoma or adenocarcinoma. Incompatibility of LLETZ specimen showing lower grade cervical dysplasia than colposcopy-directed biopsy was recorded in $23 \%$ of cases. Although we expected a lower rate of this kind of incompatibility, Herrero y Saenz de Cabezon et al. report on almost the same discordance ${ }^{2}$.

It should also be considered that high-grade dysplasia found in biopsy specimen may have been completely removed with colposcopy-directed biopsy, as well as that previously diagnosed dysplasia has not been removed by LLETZ technique. This assumption was considered in the study by Duesing et al. ${ }^{9}$.

Positive cone margins were found in $25 \%$ of our cases, $80 \%$ of which had positive endocervical cone margin. The prevalence of positive margins after LLETZ technique in our study was similar to the average reported in the literature ${ }^{6,10,11}$. A meta-analysis by Jiang et al. revealed a similar prevalence of positive margins after LLETZ (22\%; 343/1595), and so did a meta-analysis by Gheaem-Maghami et al. $(23 \%)^{6,12}$.

The most compromised margins in our study were endocervical margins (80\%), as in other studies in the literature ${ }^{13}$. Although the finding of endocervical positive margins is of greater concern, it need not necessarily confirm the presence of residual disease $\mathrm{e}^{10,13,14}$.

There are many disagreements about cone margins following LLETZ, so long-term follow up is important, regardless of the outcome of margin status ${ }^{11}$. Margin status is of particular importance in women with carcinoma in situ $u^{11,15}$. In our study, there were four $(0.29 \%)$ patients diagnosed with invasive squamous cell carcinoma or adenocarcinoma.

When cervical canal biopsy is performed during surgical procedure, the result correlates with endocervical margin status, so it can be considered as an important item in further workup ${ }^{16}$. Cervical canal biopsy result was positive in $18 \%$ of our cases.

It should be considered that residual disease is more frequent in women with positive margin status $^{16,17}$. Although LLETZ technique is superior in many ways to other excisional techniques, some reports claim that thermal artifacts and specimen fragmentation can have negative impact on histopathologic interpretation ${ }^{18,19}$. According to the National Health Service Cervical Screening Programme (NHSCSP) standards from the United Kingdom, at least $80 \%$ of the specimens obtained by LLETZ technique should be in single form ${ }^{20}$. It should also be considered 
that LLETZ is a minimally invasive technique, where it is desirable to balance maximal removal of dysplastic tissue with minimal cervical damage ${ }^{17}$. Sparic et al. in their study conclude that expert colposcopists have a lower incidence of positive margins after LLETZ, as well as thermal artifacts ${ }^{21}$. Constant investment in education and training of medical staff can provide optimal results in the treatment of cervical dysplasia with LLETZ technique ${ }^{22}$.

Accurate colposcopy and its findings can help avoid overtreatment, the rate of which was higher than expected in our retrospective study. Long-term follow up is an imperative for proper assessment of the procedure success. LLETZ is a highly effective, affordable and low-cost treatment option for premalignant cervical lesions. However, it requires continuous education and training of the whole team. This method is the best choice for complete removal of the disease without unnecessary overtreatment.

\section{References}

1. Prendiville W. Large loop excision of the transformation zone. Clin Obstet Gynecol. 1995;38(3):622-39.

2. Herrero y Saenz de Cabezon R, Viela Sala C, Subirats Gomis S, Romaguera lliso A, Gomez Bellvert C. Evaluation of cervical dysplasia treatment by large loop excision of the transformation zone (LLETZ). Does completeness of excision determine outcome? Eur J Obstet Gynecol Reprod Biol. 1998;78:83-9.

3. Murdoch JB, Grimshaw RN, Morgan PR, Monaghan JM. The impact of loop diathermy on management of early invasive cervical cancer. Int J Gynecol Cancer. 1992;2(3):129-33.

4. Oz M, Cetinkaya N, Korkmaz E, Doga Seckin K, Mutlu Meydanli M, Gungor T. Optimal cone size to predict positive surgical margins after cold knife conization and the risk factors for residual disease. J Turk Ger Gynecol Assoc. 2016;17:159-62. DOI: https://dx.doi.org/10.5152\%2Fjtgga.2016.16066.

5. Kyrgiou M, Koliopoulos G, Martin-Hirsch P, Arbyn M, Prendiville W, Paraskevaidis E. Obstetric outcomes after conservative treatment for intraepithelial or early invasive cervical lesions: systematic review and meta-analysis. Lancet. 2006; 367:489-98. DOI: https://doi.org/10.1016/S0140-6736(06) 68181-6.

6. Yan-Ming Jiang, Chang-Xian Chen, Li Li. Meta-analysis of cold-knife conization versus loop electrosurgical excision procedure for cervical intraepithelial neoplasia. OncoTargets Ther. 2016. DOI: https://dx.doi.org/10.2147\%2FOTT.S108832.

7. Brun JL, Youbi A, Hocke C. Complications, sequelae and outcome of cervical conizations: evaluation of three surgical technics. J Gynecol Obstet Biol Reprod. 2002;31(6):558-64.
8. Noehr B, Jensen A, Frederiksen K, Tabor A, Kjaer SK. Depth of cervical cone removed by loop electrosurgical excision procedure and subsequent risk of spontaneous preterm delivery. $\mathrm{Ob}$ stet Gynecol. 2009;114:1232-8. DOI: https://doi.org/10.1097/ AOG.0b013e3181bf1ef2.

9. Duesing N, Schwarz J, Choschzick M, Jaenicke F, Gieseking F, Issa $\mathrm{R}$, et al. Assessment of cervical intraepithelial neoplasia (CIN) with colposcopic biopsy and efficacy of loop electrosurgical excision procedure (LEEP). Arch Gynecol Obstet. 2012;286:1549-54. DOI: https://doi.org/10.1007/s00404012-2493-1.

10. Lubrano A, Medina N, Benito V, Arencibia O, Falcon JM, Leon L, Molina J, Falcon O. Follow-up after LLETZ: a study of 682 cases of CIN 2-CIN 3 in a single institution. Eur J Obstet Gynecol Reprod Biol. 2012;161:71-4. DOI: https:// doi.org/10.1016/j.ejogrb.2011.11.023.

11. Chen Y, Lu H, Wan X, Lv Weiguo, Xie X. Factors associated with positive margins in patients with cervical intraepithelial neoplasia grade 3 and postconization management. Int J Gynecol Obstet. 2009;107:107-10. https://doi.org/10.1016/j.ijgo. 2009.05.027.

12. Ghaem-Maghami S, Sagi S, Majeed G, Soutter WP. Incomplete excision of cervical intraepithelial neoplasia and risk of treatment failure: a meta-analysis. Lancet Oncol. 2007;8 (11):985-93. DOI: https://doi.org/10.1016/S1470-2045(07) 70283-8.

13. Bittencourt DD, Zanine RM, Sebastiao AM, Taha NS, Speck NG, Ribalta JCL. Number of fragments, margin status and thermal artifacts of conized specimens from LLETZ surgery to treat cervical intraepithelial neoplasia. Sao Paulo Med J. 2012; 130(2):92-6. DOI: http://doi.org/10.1590/S1516-318020120 00200004.

14. Garcia Ramos AM, Garcia Ramos ES, Barroso dos Reis HL, Bueno de Rezende R. Quality evaluation of cone biopsy specimens obtained by large loop excision of the transformation zone. J Clin Med Res. 2015;7(4):220-4. DOI: http://dx.doi. org/10.14740/jocmr1951w.

15. Felix JC, Mudersoach LI, Duggan BD, Roman LD. The significance of positive margins in loop electrosurgical cone biopsies. Obstet Gynecol. 1994;84:996-1000.

16. Kliemann LM, Silva M, Reinheimer M, Rivoire WA, Capp E, Reis R. Minimal cold knife conization height for high-grade cervical squamous intraepithelial lesion treatment. Eur J Obstet Gynecol Reprod Biol. 2012;165:342-6. DOI: https://doi. org/10.1016/j.ejogrb.2012.08.016.

17. Serrati M, Siesto G, Carollo S, Formenti G, Riva C, Cromi A, et al. Risk factors for cervical intraepithelial neoplasia recurrence after conization: a 10-year study. Eur J Obstet Gynecol Reprod Biol. 2012;165:86-90. DOI: https://doi.org/10.1016/j. ejogrb.2012.06.026.

18. Bharanthan R, Sagoo B, Subramaniam A, Larsen-Disney P, Fish A. LLETZ specimen fragmentation: impact on diagnosis, 
outcome, and implications for training. J Obstet Gynecol India. 2013 Oct;63(5):332-6. DOI: https://doi.org/10.1007/s13224012-0332-8.

19. Montz FJ, Holschneider CH, Thompson DR. Large-loop excision of the transformation zone: effect on the pathologic interpretation of resection margins. Obstet Gynecol. 1993;81:976-82.

20. Luesly D, Leeson S. Colposcopy and Programme Management. Guidelines for the NHS Cervical Screening Programme. Sheffield, UK: NHS Cancer Screening Programmes Publication No. 20;2010.
21. Sparic R, Tinelli A, Guido M, Stefanovic R, Babovic I, Kesic V. The role of surgeons' colposcopic experience in obtaining adequate samples by large loop excision of the transformation zone in women of reproductive age. Geburtsh Frauenheilkd. 2016; 76:1339-44. DOI: $10.1055 / \mathrm{s}-0042-113773$.

22. Butorac D, Djakovic I, Grdic Rajkovic M, Gall V, Kuna K, Kraljevic Z. Prediction of cervical epithelial lesion level in patients with positive cytologic findings using colposcopic classification Rio De Janeiro 2011. Eur J Gynaecol Oncol. 2018; 39(3):372-6. DOI: 10.12892/ejgo3719.2018.

Sažetak

\section{DVADESETOGODIŠNJE ISKUSTVO PRIMJENE VELIKE DIJATERMIJSKE PETLJE (LLETZ) U EKSCIZIJI TRANSFORMACIJSKE ZONE VRATA MATERNICE U KBC-u SESTRE MILOSRDNICE}

\section{Butorac, B. Škrtič, M. Čukelj, K. Kuna i I. Djaković}

Prikazuje se 20-godišnje iskustvo u primjeni tehnike large loop excision of the transformation zone (LLETZ) na Zavodu za opću i onkološku ginekologiju Klinike za ženske bolesti i porodništvo, KBC Sestre milosrdnice. Ova retrospektivna studija obuhvatila je 1407 bolesnica s cervikalnom displazijom liječenih ovom tehnikom u razdoblju od 1995. do 2016. godine. Metoda LLETZ najčešće se izvodila u dobnoj skupini od 25 do 35 godina (51\%), zatim u dobnoj skupini od 36 do 45 godina $(22 \%)$, dok je najmanje zastupljena skupina bila ona iznad 65 godina (2\%). Histopatološki nalaz skvamozne intraepitelne lezije niskog stupnja nađen je u 23\%, a skvamozna intraepitelna lezija visokog stupnja ili lošiji nalaz u $77 \%$ bolesnica. Pozitivni rubovi kao znak moguće rezidualne displazije nađeni su u $25 \%$ konusa, od kojih je $80 \%$ uključivalo pozitivan endocervikalni rub. U 18\% slučajeva biopsija cervikalnog kanala je bila pozitivna. U zaključku, točno izvođenje kolposkopskog pregleda pomaže da se izbjegne prekomjerno liječenje koje je u našoj studiji bilo više od očekivanog. Dugoročno praćenje nužno je za pravilnu procjenu uspješnosti zahvata. Ova metoda je najbolji izbor za potpuno uklanjanje bolesti bez nepotrebnog prekomjernog liječenja, ali zahtijeva trajnu izobrazbu i obuku cijeloga tima.

Ključne riječi: Konizacija; Cervikalna intraepitelna neoplazija; Cerviks uterusa, displazija; Kolposkopija; Hrvatska 